\title{
EXPLORING THE PERFORMATIVE FUNCTION IN LITERARY TRANSLATION: THE TRANSLATOR'S PURPOSE
}

\author{
Gabriela Miššiková
}

\begin{abstract}
This paper examines the application of text-act theory in literary translation, attempting to evaluate its efficacy in the analysis of larger texts, such as novels. The texts that form the material basis for this examination are the Slovak novel Dunaj v Amerike (2010) and its (authorized, unpublished) English translation Danube in America (2016). The main research objective is to compare the performative function in the Slovak source text (ST) and the English target text (TT), implementing the concept of the pragmatic translator as suggested by Morini $(2008,2012)$. Aiming to discover the relationship between the performative function of the TT and its actual perception by TT readers, the research project was realised involving the participation of the translators ${ }^{1}$ and TT recipients.
\end{abstract}

\section{Key words}

literary translation, text act, translation as discourse, performative function

\section{Introduction}

Pragmatic aspects of context and discourse in translation have always been recognised as an important feature of translation theory and practice. The theme is discussed in detail by Hatim and Mason (1990: 68-69), who incorporate the term 'pragmatic action' (referring to speech acts, implicatures, presuppositions, text act, etc.) along with communicative transaction and semiotic interaction/ intertextuality into their model of the "three dimensions of context". Introducing the translator as mediator, they discuss the major principles involved in the process of translating, namely the communicative, the pragmatic and the semiotic (ibid.: 237-238). Their work bears relevance to this paper by means of putting forward the notion of the 'text act' and viewing the process of translating a text as 'action' (ibid.: 76-79). Hatim and Mason's ideas (1990) are elaborated in the conception of the pragmatic translator, which, as introduced by Morini, centres on the notion of the text act (Morini 2008, 2012). Morini (2008: 33-34) acknowledges that his approach stems from functional linguistic theories, such as the taxonomies of language functions created for use in translation studies by Bühler $(1934,1982)$, and further elaborated in Reiss (1969), and Reiss and Vermeer (1984, 1991), and Koller (1979). He views as their main contribution their attempt to leave behind the a-contextual approach and "establish a connection between language and world, text and context" (Morini 2008: 35). By placing a primary emphasis 
on texts functioning and text acting, the pragmatic approach to translation differs from the views usually presented by scholars within descriptive translation studies (cf. Even-Zohar 1978, Toury 1995, Hermans 1999).

The pragmatic approach to translation requires viewing pragmatics as a linguistic concept, which is defined as "fundamentally concerned with communicative action and its felicity in context, investigating action with respect to the questions of what action is, what may count as action, what action is composed of, what conditions need to be satisfied for action to be felicitous, and how action is related to context" (Fetzer 2011:23). Accordingly, the main domain of micro-pragmatics can be outlined by the concepts central to the methodology of pragmatics, such as deixis, presupposition, implicature and speech acts. The study of implicatures often includes exploration of presupposition and politeness, also. The distinction between the micro-pragmatic and macro-pragmatic perspective becomes useful when describing particular concepts, such as the proposition of an utterance, its illocutionary force, and the range and kinds of effect the utterance is able to bring about (Cap 2011: 51). In this respect, the concept of the pragmatic translator (Morini 2012) focuses on "actions and processes" from the macropragmatic perspective. Accounting for the main aspects of pragmatic domain as applied in translation studies, Morini introduces three main metatextual categories, which he calls functions: the 'locative', the 'interpersonal' and the 'performative function' (ibid.: 13). This paper focuses on the exploration of the 'performative function', which takes logical and chronological precedence over the interpersonal and locative functions since "the translator, or the translator scholar, first has to understand what the source text [...] 'does' or 'should do' and that understanding will guide his/her choices or intuitions as far as the other pragmatic functions and the other linguistic levels of translation are concerned" (ibid.: 14).

\section{Introducing the source text}

Dunaj v Amerike (Danube in America, Hvorecky 2010) is an ambitious work by the recognised Slovak writer Michal Hvorecky, whose books are regularly published in Slovakia and translated into Czech, Polish, German, Hungarian, Slovenian and other languages. The story of the novel takes place on a river cruise ship called America, which transports retired American tourists in leisurely luxury. The cruise starts at the source of the river Danube and ends at its mouth on the Black Sea. For the passengers and the Eastern European crew, the Danube becomes a method of delivery into a series of towns on the Danube with disparate histories, populations and cultures. The plot develops on several levels, employing an array of light motifs and frequent changes of 
location and time frame. The main protagonists of the novel are Martin, a young Slovak intellectual and struggling translator who is also the Slovak tour guide on the cruise ship, and his troubled fellow-traveller and life-obsession Mona. The multinational East European members of the crew, the tour guides who interact with the American tourists in the cities they visit in Eastern Europe and the Balkans, and a range of diverse personalities among the American passengers complete the vibrant mosaic of characters. The novel is often referred to as autobiographical due to its numerous personal recollections and as a crime novel, since several murders occur on the ship, and the motif of the femme fatale, in the shape of Mona, provides some bitter-sweet romance to the plot. The author himself agrees that the novel can be best characterised as "a blend of travelogue, mystery and love story" (Šlinská 2010). The multifaceted character of the novel is reflected in the variety of titles the novel received in translation. For instance, in Czech the title reads Smrt v Americe (Death in America), in German Tod auf der Donau (Death on the Danube). The Serbian, Bulgarian and Hindi translators opted for the original title The Danube in America (Dunav u Americi in Serbian, Dunav v Amerika in Bulgarian), and the American translators decided for the title Danube in America. The Polish and English translations are completed but have not been published yet. ${ }^{2}$

The decision to work with this particular Slovak novel and its English translation was determined by several factors, among which were the ambivalent attitude towards the novel on the part of Slovak critics (cf. Gregor 2010, Mrva 2010, Prokopčák 2010, Štrompová 2010), the uncommon richness of themes elaborated in the novel, and Hvorecky's status as a recognised contemporary Slovak writer and public figure. Yet most scholarly interest has focused on the performative dimension of the novel: almost all of the author's purposes raise questions about the intentionality and 'appropriateness' of the novel both for the native ST reader and the English-speaking TT reader. To see how the writer's purposes were deciphered by the translators and effectively translated for the (originally American) intended readership was the centre of interest for this research. Transforming the novel in its complexity from a socially and culturally specific context into a different target culture and language appeared to be a very demanding task, mainly due to the anticipated lack of specific background knowledge of the intended (American) readership, as well as the attempted mocking of American passengers as one of the major motifs developed in the ST. The unique opportunity to discuss a translation in progress with the translators in person, as well as the fact that hardly any contemporary Slovak novels are translated into English, also played a role. However, the main research question remains whether the concept of the pragmatic translator can illuminate the type of problems mentioned above. 


\section{The performative function as author's purpose}

Foregrounding the role of translator and intended reader is recognised as one of the benefits of applying the pragmatic approach to translation. Exploring the performative function in literary translation primarily means discussing the translators' purposes: what they attempt to achieve by the translation and how the TT interacts with the receiving culture and intended readership. In Hvorecky's own words, his purpose was to share personal experiences (he worked for two years on an American cruise ship), evoke his childhood in socialist Czechoslovakia, remember old Bratislava (via pictures of the Danube and old Pressburg), promote the historical and cultural capital of the Danube region (the beauty and well-preserved grandeur of Austria in contrast with the poorer and more unkempt Romania), and convey a critique of post-communist East European countries (e.g. the corruption of tour guides and their cheating of clients, their background as smugglers, drug dealers, etc.). During his work on the Danube he sensed a certain literary potential and despite working hard for the travel agency he was still able to process the rich source material the river provided. His protagonist represents aspects of the author today coupled with his past experiences. Martin wants to earn a living from literature and translation, but reality makes this dream impossible and forces him to change profession. Hvorecky's purpose in writing the book, which will promote the region and its culture, including all the contrasts between 'Western' and 'Eastern' Europe, became more justified when he discovered that in European literature Danube novels are practically non-existent (Gregor 2010).

The study of the performative function reflects the essence of speech act theory as formulated by its famous founder: "every utterance aims at achieving something and achieves something" and "to say something is to do something; or [...] by saying or in saying something we are doing something" (Austin 1962: 18). Reflecting this idea in translation analysis, the aim of the paper is to see whether the intended effects of the original text are the same as those achieved in its translation. Considering the intended effects as inscribed in the source text requires the identification of connections between the utterances, the co-text, and the situational context. In this sense, the entire text of the analysed novel becomes of crucial importance. It modifies the reader's perception of the world. The translator acts as a knowledgeable reader, reading the ST with particular intentions in mind. However, the entire text of the novel modifies his/ her perception of the world by 'doing something' to his/her world. Translating the ST, the translator aims "at 'doing what the source text does' in the target language - with all the obstacles posed by linguistic and cultural barriers - he/she 
must translate a 'text act' rather than a mere text" (Morini 2012: 15). Before approaching the analysis of the ST and the TT, the main views on the term text act are summarised below.

\section{The notion of text act}

Viewing texts as communicative items, Hatim and Mason (1990) consider the role of context and distinguish its three dimensions. In addition to the communicative dimension, they emphasise the role of the pragmatic dimension, which brings into focus "values relating to the ability to "do things with words" (ibid.: 57). The pragmatic dimension is closely related to the third, semiotic dimension of discourse, "treating a communicative item, including its pragmatic value, as a sign within a system of signs" (ibid.). The notion of text act first appears as part of pragmatic action in the discussion of text, structure and texture (ibid.: 58) and further on, in a broader context, as part of a larger scale considering the (rhetorical) purpose of text, defined as "preserving equivalence of intended meaning for intended purposes" (ibid.: 237). Hatim and Mason (ibid.: 77-78) use the term text act to shift attention from the study of individual speech acts, usually studied in relation to individual sentences, towards more complex structures. Thus "the cumulative effect of sequences of speech acts leads to perception of a text act, the predominant illocutionary force of a series of speech acts" (Horner 1975, as cited in Hatim \& Mason 1990: 78). The authors exemplify the application of the notion of text act in the analysis of texts of smaller size and distinctive genre characteristics, such as newspaper columns, brief reports, instruction guides, etc. They occasionally use samples from poetry and consider the notion of the text act in interpreting too. Applications of text-act theory in literary translation, where texts often display diverse characteristics and are longer than other texts and functions may be somewhat harder to define, and less manageable. Dealing exclusively with literary translation, fiction and poetry, Morini suggests viewing the text act as "subsuming all the performative forces displayed by a text" (2012: 34). He further considers the effects of dismantling text acts into "a series of speech acts" and arrives at the conclusion that this has no bearing on their overall force and effect. While Hatim and Mason's (1990) explanation of a text act seems to reflect the notion of the dominant function as introduced by Reiss (1969: 83), in Morini's view "a text act can accommodate the dominant as well as other functions, not to mention genre and other performative qualities" (2012: 34). In an attempt to exemplify the suggested pragmatic approach, he provides two examples of text acts, discussing how translators decide on the strategies to be employed, the required degree of planning, etc. (ibid.: 36). 


\section{Data collection for pragmatic analysis}

The presented study reflects on two sets of data - personal communication with the translators and a corpus of responses collected from American university students. The data gained from both translators were obtained via personal meetings, email communication and a questionnaire combining questions on theoretical issues (e.g. the pragmatic/performative essence of the translation norms of a society, target-oriented plausibility, translating voices - translating people, etc.) and practical translation problems (e.g. the pragmatic nature of the decisions translators had to make, how the translated novel may interact with and modify or organise the world outside its paper borders, which specific translation situations were difficult to solve/agree upon, were there disagreements or arguments about certain translation situations, etc.). These data are marked as 'translators' responses' and further in the text are marked as TRs.

The group of TT respondents consisted of 27 American students enrolled in the course World of Ideas (WOI), taught by Professor Mark Lencho at the University of Wisconsin-Whitewater (WI, USA) in the fall term 2018/19, where I pursued research as a Fulbright scholar during the given term. Students' responses were obtained via guided seminar discussions, a questionnaire and final term papers. The discussion topics included reflections on the literary value of the novel, students' views on the relationship between author and reader, their perception of the purpose of presenting Martin's childhood reminiscences, perception of how DIA shows the extent to which politics are implicated in how we interact with one another, why Hvorecky presents his readers with the given historical data and images, etc. The questionnaire was designed in two parts. Part I. ("Implicatures: Understanding Utterances") focused on the role of translators' notes. In the form of a multiple-choice questionnaire, students were asked to choose the option that best expressed their opinion on the use of notes in five short sample texts from DIA. There were four options given: Without reading the note 1) I wouldn't know what is ..., but reading fiction, I wouldn't mind, 2) I wouldn't know what is ... and it would disturb me, 3) I would be probably able to guess what is ... based on the situational context, 4) I would understand easily/can guess that ...). Part II. ("Implicatures: Inferential Processes") aimed at eliciting information on inferential processes, asking students to describe all the conversational implicatures they were able to infer in seven text samples (including examples discussed in Section 7) from DIA. The topics for term papers were focused either on literary elements (e.g. the Danube Personified, Furthering the Metaphor of the Ship, Round and Flat Characters, Martin as Sisyphus: How to Unpack Allusions, Conflict and the Connection with Movement, etc.) or the benefits of the American publication of Danube in America. 
These data are marked as 'readers' responses' and collectively referred to as RRs further in the text. In awareness of all the limitations of the research project, RRs are seen as a complementary yet important source of information, which can illustrate how the overall view of the ST adopted by the translators was reconstructed in the TT and presented to the TT readers.

\section{Text-act theory as opposed to genre theory and text typologies}

In a form of preface to the analytical part presented in Section 7, the proposed application of text-act theory in translation is examined, considering potential benefits in contrast with genre theory and text-type taxonomies. The aim is to scrutinise in particular the two major claims made by Morini (2012: 34-36).

The first claim is that the concept of text act enables us to "describe the performative dimension of a text much more exhaustively" (ibid.: 34). The argument is that text-types are classified mainly according to their dominant function, for instance as descriptive, narrative, argumentative, literary, etc. (cf. de Beaugrande 1980: 197), which is regarded as a reduction of their communicative purposes presenting a text as having "one encompassing goal" (Morini 2012: 34). Similarly, "the concept of genre covers the ostensive side of the performative function", which means that "the text ostensively declares its affiliation to a certain category" (ibid.). The ST in question represents a category of "so-called mixed genres, which blend one variety with another: e.g. mock-epic, tragi-comedy" (Wales 1989: 207). As demonstrated in Sections 2 and 3, Danube in America as a modern novel declares its affiliation to a genre category by its considerable level of formal experimentation, displaying the expressive function as most dominant: its genre characteristics are determined by a set of structural and stylistic qualities, exhibiting certain tones and attitudes, dealing with particular subject matter, offering a world view to the reader. These aspects were considered crucial in their complexity and the translators regarded them as the most important part of the performative function of the ST: "Ifeel like we have a responsibility to spread Slovak culture and understanding of what the Central and East European is going through ...", "through linguistic translation there's a responsibility to do cultural translation ...” (The Bat of Minerva 2015). Aiming to create a TT satisfying all communicative purposes, the translators had to attend to a number of challenging aspects of the ST and make decisions about translation strategies at both a micro and macro textual level. For instance, at the micro level they had to decide how to translate the "multi-lingual mash-ups" of Captain Atanasiu (Hudecová 2014), items of culture-specific lexis with no counterparts in the target language, wordplay that becomes lost in translation, etc. On a larger scale, the translators discussed the title of the TT and decided to 
give preference to Danube in America over The Danube in America, which, in their view, better captures the symbolism attributed to the River Danube (TRs). Another problem the translators had to cope with was raised by the size and nature of the footnotes, which they considered necessary, due to the large amount of geographical, historical and culture-specific information mentioned in the ST. The translators see themselves as mediators and consider introducing different cultures to the American reader as a vital role. At the same time, they view this 'mediating' purpose as an inherent part of the performative function of the TT they intended to create. Compensating for missing background knowledge and experience they include more than 80 footnotes $^{3}$ in the TT. The majority of them provide information on the history of Slovakia and the given regions of Eastern Europe, clarify cultural references and explain cultural and historic contexts. As such, they were considered essential for adequate perception of the TT in the receiving culture. It has to be noted that, thanks to their personal and professional background, the translators were well equipped to recognise the entire complexity of the communicative purposes and performative function of the ST. Approaching the ST as experienced and knowledgeable readers, they regarded the ST as a representative of contemporary Slovak literature, a phenomenon that has to be perceived and understood within the source culture, including a variety of specific artistic, social and cultural contexts. Considerations regarding the effects of reading the ST, and introducing its translation to an American readership, came as a natural part of the planning. Primarily, the translators considered what the ST aims 'to do' in the world, how the text can 'act' in the world of the ST and TT readers, as well as their own (TRs). Doing so, the translators have viewed the ST as a particular text act and considered different aspects, which go beyond the genre or text-type characteristics. The TT maintains the original text as 'acting' in its full performative force. However, the translators' viewing the TT as 'acting' and 'performing' in the context of the receiving (target) culture does not provide enough evidence that text-act theory alone can guarantee describing the performative dimension of a text more exhaustively than genre theory and text-type taxonomies.

As for the second claim that "unlike genre theory, which presupposes a high degree of intentionality, text-act theory does not exclude intentionality, but can dispense with it" (Morini 2012: 34), its acceptability in literary translation is arguable: translating a literary text without taking into account the writer's intentions, disregarding the intended recipients and receiving culture could cause doubts about the translation's appropriateness. Yet situations when translators are 'forced' to do without intentionality are conceivable, such as literary texts where intentionality, defined as "the assumption of a recognition of the writer's 
intention", is less clear or even impossible to recognise (Wales 1989: 254). On the other hand, Morini's (2012) claim enhances the importance of the translators' background and 'readiness', since the assumptions they make about the ST are of crucial importance in respect to the TT's 'suitability' for the TT readers and further prospective of the translated novel in the receiving culture.

The assumed and recognised intentionality of the ST became an important, yet perhaps not crucial, feature in the translators' decisions when carrying out the translating act. Correspondingly, they were aware that TT perception would be determined by adequate processing of ST intentionality, adopting its main aspects for the intended TT readers. As presented in Section 7, the ST intentionality was successfully recreated. The TT readers appreciated learning about different cultures, countries and their history, acknowledged perception of literary aesthetic values and noted that reading the TT had improved their soft skills, making them more communicative and understanding (RRs). The TT also 'acts' upon the translators' lives. Professionally, they earned scholarly appreciation and gained encouraging responses from their colleagues and students. Personally, they managed to reactivate their contact with Slovakia and Bratislava, recollecting their personal experiences while living there. The sum of these and similar aspects supports the view of the process of translating a novel as translating a text act. However, discussion of the translators' views and attitudes towards translating the ST, and the collected responses of the TT readers, do not provide sufficient evidence for the preference of text-act theory to genre and text-type methodology. ${ }^{4}$

\section{Performative function in the TT}

Exploring the performative function in literary translation primarily means discovering to what extent the translators recognised the writer's purposes in the ST, and recreated them in the TT. In view of the concept of the pragmatic translator presented above, the ST requires translation as a 'text act' so that it can 'act' correspondingly for TT readers, in the target language and target culture. These aspects invite observations of macro-structures, such as paragraphs and chapters, making inferences based on contextual considerations. The level of successful determination of the functions and effects of these text units can signal the performative function of the TT. The examples discussed below aim to illustrate how TT readers interact with the TT and perceive its performative function, as well as the fact that a comparative analysis of the performative function cannot do without attaining pragmatic aspects at the micro-level of the ST and the TT. Regardless of their formal characteristics (narratives versus conversational exchanges), the parallel excerpts given below display elements of performative 
force, which, on a larger scale, combine into the performative function of the TT. Among the most significant writer's purposes the following three can be pointed out: 1) recollecting the memories of his childhood in Bratislava and communist Czechoslovakia, along with pointing out the differences between the 'West' and 'East'; 2) providing a critique of tourism practices, symbolised in the novel by the American Danube Cruises company (ADC), and using this theme to familiarise readers with the cultural capital of Eastern Europe; 3) seeing the American tourists "as a projection of Western commercial incursions into the expanding market represented by the so-called New Europe" (Hudecova 2014), together with the mocking of the American tourists as being self-centred and ignorant towards the world outside the USA. The discussion below takes account of the TT readers' responses (marked as RRs) as specified in Section 5.

Nijaké iné dievča nemalo také západne znejúce meno, do Martinovej triedy chodili samé Katariny, Zuzany a Hany. Spolužiačky, chudé ako cverna, vysoké a vyhúknuté, nosili čudné obrovské nohavičky a páchli chudobou. Mona sa aj inak obliekala. Naozaj sa s ním chcela rozprávat'. (DVA: 82)

[No other girl had such a western-sounding name-Martin's class was filled with Katarinas, Zuzanas and Hanas. His female classmates, skinny beanpoles, tall and awkward and gangly, wore odd oversized underwear, and smelled like poverty. Mona dressed differently, too. She really wanted to talk to him. (DIA: 89)]

The awareness of the differences between the 'West' and 'East' during the socialist regime comes as part of Martin's recollections of his childhood, when he first met Mona, a girl 'from the other side of the river Danube', the only child of a wealthy civil servant, who symbolises his first contact with a different and more interesting 'Westernised' world. The main protagonist's awareness of social and cultural gaps becomes one of the main thematic lines developed in the ST. The TT readers' responses imply a lack of historical and cultural background information and any relevant experiences. The TT 'acts' differently upon the American readers, who were not fully equipped to recognise the complexity of conversational implicatures associated with the propositions expressed in Mona dressed differently, she really wanted to talk to him, and smelled like poverty. In the ST, Mona's different social status, Martin's sensitive personality, and his need to share and connect are implied. The TT readers were able to make general inferences about cultural differences between where Martin grew up and America, his awareness of so-called Western culture, his viewing Mona as different from others he has encountered, etc. However, they were not able to recognise particularised conversational implicature associated with the use of traditional Slovak names, such as Katarína, Zuzana and Hana. Approaching 
the TT from the different perspective of their native culture, TT readers did not recognise the communicative purpose of using these names, their responses implying a certain degree of misinterpretation: 1) this gives a picture to think of the characters being in Slovakia, 2) Martin isn't used to hearing weird names, 3) "smelled like poverty" implies that it is not a positive picture, 4) these names are not heard of in America, I could not pronounce them myself, 5) not quite sure what is meant when he says "it smells like poverty", 6) strong stereotypes can affect your view, 7) negative way of thinking (RRs). The TT readers' confusion about this type of culture-specific aspect presented in the TT was noticeable but clarified without difficulty in seminar discussions. In spite of the weak performative force of Example 1, the writer's purpose to recollect the memories of his childhood and communist Czechoslovakia remains an inherent part of the performative dimension of the ST. The translators had to consider a translation strategy designed to substitute for the lack of cultural context and background information of the anticipated (originally American) TT readers. They decided to remain 'faithful' to the ST and avoided modifications and supplementary descriptions integrated directly into the TT. Providing for necessary crosscultural contexts and background knowledge they opted for a well-prepared and richly elaborated corpus of footnotes.

Another part of the performative function in DIA is the writer's purpose to mock ADC protocol and its attitude towards passengers. On a larger scale a critique of tourism practices can be perceived. The phenomenon of political correctness was imported to Europe from the USA and soon became perceived as misused and tainted with irony. As such, it can be seen as a natural part of mocking ADC's image, its PR strategies and attitude towards employees. The phenomenon is well known in the target culture, so the TT readers were able to recognise the implied irony and criticism. Example (2) shows Martin's feelings after being officially appointed to the position of "Director".

(2) No nenamýšlal si bohviečo, pretože sa vzápätí dozvedel, že honosnými názvami pre podradné džoby sa to tu len tak hemžilo. Riaditelia rástli v ADC ako žihl'ava pri plote. Vo firme sa aj chyžná nazývala Chairwoman of Housekeeping, plavčik zasa Chief Nautical Officer a posledný strojnik General Engineer Commander. (DVA: 12)

[He did not think too much of it, however, since in short order he found out that high-sounding titles for menial jobs were very common here. Directors in ADC grew like weeds by fences. The company called their cleaning lady "Chairwoman of Housekeeping"; the lifeguard was the "Chief Nautical Officer," and the least of the mechanics was called "General Engineer Commander." (DIA: 8)] 
The frequent use of English expressions throughout the ST generally implies a cross-cultural blend of the East European and American contexts. The TT readers are deprived of bilingual effects lost in English translation, and make inferences about implied messages based on other related contexts. In Example (2), the generalised conversational implicature associated with the propositions expressed in "nenamýšlal si bohviečo [He did not think too much of it]" and "honosnými názvami pre podradné džoby sa to tu len tak hemžilo [high-sounding titles for menial jobs were very common here]" was recognised by the TT readers easily: Martin had no high hopes or unrealistic expectations when taking the job. As the story unfolds, the TT readers make further inferences about Martin's character, his attitude towards the job of tour guide he had taken to escape the life of an underpaid intellectual, teaching assistant and translator at Comenius University in Bratislava, trying to forget Mona and yearning to see other countries, and earn some money, too. The markedness of the bilingual clash is neutralised by the English translation and so the TT readers perceive narrations such as in Example (2) as mainly informative and descriptive, with elements of irony and criticism, yet of limited performative force. They are well aware of the act of business promotion, a sense of hierarchy in public institutions and commercial companies reflected in the notion of political correctness, since they are part and parcel of their native culture. As noted earlier, Example (2) performs differently with the ST readers, who are confronted with components of a different language and different social and cultural phenomena, which, even though not entirely unknown in the ST culture, still generate some flavour of 'otherness'. In spite of the different intensity of the performative force in the ST and the TT as illustrated in Example (2), the writer's purposes accumulated in the performative dimension of the ST are successfully re-created in the TT. Presenting the company as corrupt, misleading of clients, criticizing their strategy for recruiting staff and selecting clients, etc. are all inscribed in the TT (RRs).

One of the most challenging aspects of the ST (regarding the intention to create the TT for an American readership) can be the writer's purpose to mock the American tourists as being self-centred and ignorant towards the world outside the USA. Indeed, the ST contains many clichés and stereotypical opinions of Americans, portraying them as stupid, spoilt, lazy and obese. Example (3) illustrates typical conversational exchanges between American passengers and the main protagonist Martin, their Slovak tour guide. 
(3)

"Kde žije ten Mozart?" spýtala sa po koncerte Lucy Stanská.

Medzi obočím sa jej vytvorila zamyslená vráska a zrejme bolela.

“Žial', už nežije, nedávno zomrel. Asi pred tromi týž̆dňami.”

"To mi je l'úto."

"Aj mne. Narodil sa v Salzburgu."

"To je v ktorom štáte?"

"V Rakúsku."

"A tam tiež pôjdeme?"

"Už tam sme. Viedeň je hlavné mesto." (DVA: 149)

["Where does Mozart live?" Lucy Stansky asked after the concert.

A pensive furrow appeared between her eyebrows, and it probably hurt, too.

"Unfortunately, he's not alive anymore. He died recently, about three weeks ago."

"I'm sorry about that."

"Me, too. He was born in Salzburg."

"What country is that in?"

"In Austria."

"Are we going to go there, too?"

"We're there already. Vienna is the capital city." (DIA: 170)]

On a larger scale, the act of mocking American passengers can be seen as part of the mocking of ADC protocol and criticizing tourism practices in general. In this sense, Examples (2) and (3) both illustrate the components of the performative force as inscribed in the micro-textual structures of the ST and TT and accumulated into the performative force of the text act of mocking observable at the macro-level.

As illustrated by the TT readers' responses, the performative function of this text act is perceived as the incapacity of the American passengers to cope with a wide-ranging amount of new information and experiences. The TT readers (American university students, who took part in the project) were also able to appreciate the humour and irony implied in Example (3) and readily admitted that "Americans only really know about America" and so "True expedition and experience are lost because Americans do not really experience life outside the US as they should." They expanded on the idea in their term papers: "The book offers a valid critique of the American culture. Some Americans may choose to take it as offensive; however, some of the thoughts regarding Americans from a Slovak perspective should be taken in consideration ...", "at various points throughout the book, the author describes several American stereotypes that do not cater to an American audience", "Americans were depicted as being rude, lazy, obese or overweight. Yes, Americans probably do have a serious health concern that needs to be addressed ...", etc. (RRs). The translators too share this critical viewpoint asking "Will the tourists remember anything about their 
cruise in a year or two beyond a vague feeling of aesthetic pleasure and a stamp in their passport?" and thus viewing the circumstances in which Martin makes up the stories as instances of transforming "a nominal history lesson into an act of deception, required of the American tourists so they can avoid facing the inconvenient truths ..." (Hudecova 2014).

\section{Conclusions}

In this paper, an attempt at applying the concepts of the text act and performative function in the analysis of the English translation of a Slovak contemporary novel is presented. Both concepts are central to the conception of the pragmatic translator (Morini 2008, 2012). With respect to the multi-faceted nature of the ST and apparent distance between the source and target culture, I considered the conception suitably applicable in the presented research. As demonstrated above, the conception certainly offers an interesting and fresh look at the role of translator and the process of translating in general. However, the theoretical argumentation as well as the empirical and analytical parts of the paper indicate that both concepts can be applied in the analysis of the ST and the TT only with certain limitations.

As illustrated in Section 6, the problem is mostly methodological: if we agree that a text act means "everything that a text aims to do and/or does in the world" (Morini 2012: 34), and the performative function of a text primarily means considering the writer's/translator's purposes, i.e. what they attempt to achieve by writing/translating a text, which (linguistic) methods would serve best to find out? One way in which to cope with these aspects was to pursue a small-scale research project involving the participation of the translators and TT readers. The project findings underline most of the discussion presented in this paper. As presented in the analysis and commentary in Section 7, the way the text 'performs' primarily depends on the readers' actions determined by their 'readiness' and 'preparedness' to perceive and interact with the text. Hence, it is the translators and the readers of the TT, who 'do things' and 'act' upon the text they read. One has to agree that, in this sense, the TT can influence TT readers and can 'act' in the context of their (target) culture, yet, as already generally acknowledged in pragmatics, the role of individuals receives priority in this process. Consequently, the presented analysis of the performative function in the ST and its recreation in the TT focuses primarily on the macrostructures of the TT, but cannot do without considering micro linguistic aspects. It also demonstrates that the analysis of literary translation requires an analytical toolkit, which combines the benefits of implementing pragmatic concepts with 


\section{Exploring the Performative Function in Literary Translation: The Translator's Purpose}

the analytical methods regularly used in pragmatic stylistics, conversation and (literary) discourse analysis.

As for the performative function in the analysed source and target texts, the analysis has shown that the writer's purposes were readily acknowledged and adequately reflected in the TT. The effort of the translators to act as mediators of different cultures to the American readership was readily acknowledged by the TT readers.

In conclusion, it can be stated that the conception of the pragmatic translator represents an interesting contribution which has to be viewed as rooted in and supplementary to other existing linguistic theories of translation (including Skopos theory and the theory of polysystems, cultural translation, etc.) that allow for sociological and cognitive approaches of greater intensity. Similarly, when contrasted with genre and text-type theory, no conclusive arguments that would substantiate its preference over those were obtained.

\section{Notes}

1 The translators' background bears relevance to many aspects of the present research. Eva Ruth Hudecova Copeland is a Slovak-born scholar, who received her university education in the USA and currently teaches at the Department of Cultural Studies and Comparative Literature, College of Liberal Arts, University of Minnesota (Minneapolis, USA). She first met Hvorecky in Bratislava in 2010 and they soon found out that they have a lot in common, having been born in the same year and sharing a similar personal experience of living under a totalitarian regime. Eva is editor of a critical edition of Danube in America. The edition is under consideration at numerous presses.

Mark Lencho is an Associate Professor at the Department of Languages and Literatures, College of Letters \& Sciences, at the University of Wisconsin-Whitewater (Wisconsin, USA), where he teaches linguistics, general humanities, and composition courses. He has published several articles on the relationship between the Slovak and English languages. In 2006 and 2007, he taught in Nitra under the auspices of the US Fulbright program and returned in the fall 2013 semester to teach a graduate seminar in literary translation and in 2015 to give a conference presentation entitled "A New Literary Slovak English".

Eva and Mark teamed up and started collaboration on the translation of DIA in 2010. They accompanied Hvorecky on his American promotional book tour and gave several lectures at American universities and conference presentations on translating the novel.

2 The translators of DIA did not have a publishing contract and no book market research was done either. Negotiations with publishing houses are still ongoing, yet more than two years after completion the translation remains unpublished. Some European publishers have shown interest, yet none in the USA. Around a year ago, a discussion at a pretty high level about the promise of the book for an American audience was initiated. This academic debate is still continuing, encouraged by those who have read the translated novel, mostly translators' colleagues and friends, and university students.

3 The total number of footnotes used in the TT is 87 . As for their characteristics, the majority $-39 \%$, represent cultural references. The second largest group, $25 \%$, provide information on the places and points of interests. A smaller number of footnotes is devoted to explanations of historical facts $-16 \%$, and facts related to the political context comprise $13 \%$ of the total number. Another two small groups can be identified - one explaining wordplay which is untranslatable and thus lost 
in the TT $-8 \%$, and a few footnotes related to possible perception problems of the TT readers $2 \%$. To sum up, approximately $93 \%$ of all footnotes are devoted to background information and specific contexts. The footnotes devoted to linguistic problems (such as wordplay and slang words) represent just a small portion $-7 \%$. Besides its effectiveness in explaining unknown phenomena and contexts, the size of the corpus sometimes interferes with literary-aesthetic qualities of the TT, causing unnecessary distractions to the TT readers ("the element of not knowing could also add to the story, in the sense that it is broadening the audience's perspective and intellect", RRs).

4 Some degree of misunderstanding may be due to inconsistency in using two concepts: writer's purposes (in text-act theory) and writer's intentions (in literary criticism).

\section{Acknowledgements}

I would like to thank both translators, Eva Ruth Hudecova Copeland and Mark Lencho, for sharing their professional views and experiences on translating the novel. I am in particular grateful to Professor Mark Lencho for his wonderful patience with my constant questioning and the students enrolled in the course "World of Ideas" in the fall term of 2018/19. Their genuine involvement pointed out many unique aspects of interaction between different cultures and generations. This research was supported by Fulbright Commission Bratislava, Slovakia.

\section{References}

Austin, J. L. (1962) How to do Things with Words. New York: Oxford University Press. Bühler, K. (1934/1982) Sprachtheorie: Die Darstellungsfunktion der Sprache. Stuttgart and New York: Gustav Fischer.

Cap, P. (2011) 'Micropragmatics and macropragmatics.' In: Bublitz, N. and Norrick, R. (eds) Foundations of Pragmatics. Berlin and Boston: De Gruyter Mouton. 51-75.

de Beaugrande, R. (1980) Text, Discourse and Process. Norwood, NJ: Ablex.

Even-Zohar, I. (1978) 'The position of translated literature within the literary polysystem.' Papers on Poetics and Semiotics 8. 21-27.

Fetzer, A. (2011) 'Pragmatics as a linguistic concept.' In: Bublitz, N. and Norrick, R. (eds) Foundations of Pragmatics. Berlin and Boston: De Gruyter Mouton. 23-50.

Hatim, B. and Mason, I. (1990) Discourse and the Translator. London: Longman.

Hermans, T. (1999) Translating in Systems: Descriptive and System-oriented Approaches Explained. Manchester: St Jerome.

Hudecova, E. (2014) 'The triangle and the ribbon: Bratislava, Vienna, Budapest and the Danube in Michal Hvorecky's Danube in America.' In: Capitals ACLA 2014, New York University, March 20-23, 2014, full program guide $(158,323)$.

Koller, W. (1979) Einführung in die Übersetzungswissenschaft. Heidelberg: Quelle und Meyer.

Morini, M. (2012) The Pragmatic Translator: An Integral Theory of Translation. Bloomsbury: Publishing PLC.

Morini, M. (2008) 'Outlining a new linguistic theory of translation.' Target 20(1). John Benjamins. 29-51. 
Reiß, K. (1969) 'Textbestimmung und Übersetzungsmethode.' Ruperto and Carola. Zeitschrift der Vereinigung der Freunde der Studentschaft der Universität Heidelberg 20(46). 69-75.

Reiß, K. and Vermeer, H. J. (1984/1991) Grundlegung einer Allgemeinen Translationstheorie. Tübingen: Max Niemeyer.

Toury, G. (1995) Descriptive Translation Studies and Beyond. Amsterdam and Philadelphia: John Benjamins.

Wales, K. (1989) A Dictionary of Stylistics. London: Longman.

\section{Sources}

Hvorecky, M. (2010) Dunaj v Amerike. Marenčin PT, Bratislava.

Hudecova, E. and Lencho, M. (2016) Danube in America. An unpublished authorized translation.

\section{Internet resources}

(The) Bat of Minerva (2015) Eva Ruth Hudecova Copeland, Co-translator of "Danube in America" (19.5.2015) https://www.youtube.com/watch?v=hjydYLpNVP0. Retrieved October 2017.

Gregor, Jan (2010) Hvorecký - Dunaj bol mŕtvou riekou. 14.5.2010 https://kultura.sme. sk/c/5374232/hvorecky-dunaj-bol-mrtvou-riekou.html\#ixzz5Y1OhfomU. Retrieved March 2017.

(The) Missing Slate. Author of the Month: Michal Hvorecky, (2016, Jan 7). https://themissingslate.com/2016/01/07/author-month-michal-hvorecky/. Retrieved October 2017.

Mrva, T. (2010) Stratený v prúde času (19. 5. 2010) http://www.inaque.sk/sk/clanky/ books/fiction/strateny_v_prude_casu. Retrieved March 2017.

Prokopčák, T. (2010) Hvorecký napísal výbornú knihu. Konečne. SME https://hvorecky. sk/2010/05/14/hvorecky-napisal-vybornu-knihu-konecne/. Retrieved March 2017.

Šlinská, J. (2010) Michal Hvorecký: Väčšina kritikov u nás ma úprimne nenávidí 30.7.2010 https://slinska.blog.sme.sk/c/236605/Michal-Hvorecky-Vacsina-kritikovu-nas-ma-uprimne-nenavidi.html. Retrieved March 2017.

Štrompová, A. (2010) Dunaj v Amerike - Michal Hvorecký Knižná revue 2010/14-15 https://hvorecky.sk/2010/08/16/dunaj-v-amerike-recenzia-v-kniznej-revue/. Retrieved March 2017.

Gabriela Miššíková is Professor of linguistics at the Department of English and American Studies, Constantine the Philosopher University in Nitra, Slovakia. Her background is in stylistics, pragmatics and discourse studies, and her current research focuses on the potentials of applying pragmatic concepts in the analysis of literary translation.

Address: Gabriela Miššíková, Department of English and American Studies, Faculty of Arts, Constantine the Philosopher University, Štefánikova 67, 94901 Nitra, Slovakia. [e-mail: gmissikova@ukf.sk] 